\title{
PENGARUH KRIB BAMBU TIPE PERMEABEL TERHADAP GERUSAN TEBING DI BELOKAN SUNGAI (STUDI EKSPERIMENTAL)
}

\author{
Abd.Rakhim Nanda ${ }^{1}$ Amrullah Mansida ${ }^{2}$ Anita $^{3}$ dan Yayu Sulistiawati ${ }^{4}$ \\ 1) Universitas Muhammadiyah Makassar, Indonesia \\ Email : \\ 2) Universitas Muhammadiyah Makassar, Indonesia \\ Email : amrullah.mansida@unismuh.ac.id \\ 3) Universitas Muhammadiyah Makassar, Indonesia \\ Email : anita2772@gmail.com \\ 4) Universitas Muhammadiyah Makassar, Indonesia \\ Email : yayusulistiawatyy@gmail.com
}

\begin{abstract}
Abstrak
Kerusakan Daerah Aliran Sungai (DAS) menyebabkan Gerusan tebing sungai menambah sedimentasi di dasar sungai.Penelitian ini bertujuan untuk mengetahui pengaruh karakteristik aliran di daerah krib bambu tipe permeable dan pengaruh pemasangan jarak krib bambu tipe permeable terhadap gerusan tebing di belokan sungai. Jenis penelitian yang digunakan adalah eksperimen laboratorium. Pengaruh pemasangan krib tipe permeabel terhadap karakteristik aliran dan tanpa pemasangan krib menyebabkan terjadinya perubahan karakteristik aliran di beberapa titik dari super kritis ke sub kritis dan pemasangan jarak krib bambu tipe permeabel terhadap gerusan tebing di belokan sungai berpengaruh pada volume gerusan, dimana semakin kecil jarak pemasangan krib yang digunakan maka akan semakin kecil volume gerusan yang terjadi. Hal ini diakibatkan karena krib mengalami agradasi dan degradasi di daerah krib dengan jarak yang cenderung lebih besar.
\end{abstract}

kata kunci : Permeabel, Jarak Krib, Sungai.

\begin{abstract}
Damage to the Watershed (DAS) causes the erosion of river banks to add sedimentation to the riverbed. Watershed Damage causes river cliffs to add sedimentation to the riverbed. This study aimed to determine the effect of flow characteristics in permeable bamboo crib areas and the effect of mounting permeable bamboo crib types on scouring cliffs at river turns. The type of research used is laboratory experiments. The effect of permeable type crib installation on flow characteristics and without crib installation causes changes in flow characteristics at some points from super critical to sub critical and installation of permeable type bamboo cribs to scour cliffs on river turns affect the scour volume, where the crib mounting distance is smaller which is used, the smaller the scour volume will occur. This is caused by the crib experiencing aggression and degradation in the area with a distance that tends to be larger.

keywords: Permeable, Krib Distance, River.

\section{PENDAHULUAN}

Sungai merupakan suatu saluran terbuka yang terbentuk secara alamiah di atas permukaan bumi dimana air mengalir dengan muka air bebas. Setiap sungai memiliki karakteristik dan bentuk

yang berbeda antara satu dan yang lainnya, seperti halnya sungai yang bercabang dan berkelok-kelok. Sungai ini sangat penting untuk memenuhi kebutuhan hidup manusia, sehingga keadaan ini perlu dijaga agar tetap berada pada kondisi yang baik.
\end{abstract}


Kerusakan Daerah aliran sungai (DAS) yang terjadi sebagai akibat dari perubahan tata guna lahan, pertambahan jumlah penduduk serta kurangnya kesadaran masyarakat terhadap pelestarian lingkungan daerah aliran sungai. Gejala kerusakan daerah aliran sungai dapat dilihat dari penyusutan luas hutan dan kurusakan lahan terutama kawasan lindung di sekitar daerah aliran sungai yang biasanya disertai pula dengan proses erosi dan pengendapan. Tujuan dari penelitian ini yaitu:

1) Mengetahui karakteristik aliran di daerah bangunan krib bambu.

2) Mengetahui pengaruh pemasangan jarak krib bambu terhadap gerusan tebing di belokan sungai.

\section{TINJAUAN PUSTAKA}

\section{Sungai}

Sungai merupakan jaringan alur-alur pada permukaan bumi yang terbentuk secara alamiah, mulai dari bentuk kecil di bagian hulu sampai besar dibagian hilir. Air hujan yang jatuh diatas permukaan bumi dalam perjalanannya sebagian kecil menguap dan sebagian besar mengalir dalam bentuk alur-alur kecil, kemudian menjadi alur-alur sedang seterusnya mengumpul menjadi satu alur besar atau utama. ( Joerson Loebis, dkk, 1993)

$$
\text { Bentuk - bentuk sungai dalam }
$$

Bambang Hardianto,dkk. (2014) bentuk alamiah, yang dapat kita jumpai diperlihatkan pada gambar berikut.
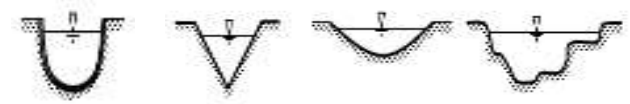

Gambar 1. Bentuk - bentuk sungai alamiah.

\section{Hidrolika Sungai}

1) Aliran Laminer dan Turbulen

Variable yang dipakai untuk klasifikasi ini adalah bilangan Reynold yang didefinisikan sebagai :

$$
R_{e}=\frac{V L}{v}
$$

Dimana:

$R_{e}=$ Angka Reynold

$V \quad=$ Kecepatan aliran $(\mathrm{m} / \mathrm{det})$

$L=$ Panjang karakteristik (m), pada saluran muka air bebas $\mathrm{L}=\mathrm{R}$.

$\mathrm{R}=$ Jari - jari hidrolis saluran $(\mathrm{m})$

$v=$ Viskositas kinematik $\left(\mathrm{m}^{2} / \mathrm{det}\right)$

Beberapa penelitian disimpulkan bahwa bilangan Reynold untuk saluran terbuka adalah :

$\begin{array}{ll}\mathrm{R}<500 & =\text { Aliran laminer } \\ 500<\mathrm{R}<12,500 & =\text { Aliran transisi } \\ \mathrm{R}>12,500 & =\text { Aliran turbulen }\end{array}$

2) Aliran Kritis, Sub kritis dan Super kritis

Parameter tidak berdimensi yang membedakan tipe aliran tersebut adalah 
angka Froude $\left(\mathrm{F}_{\mathrm{R}}\right)$ yaitu angka perbandingan antara gaya kelembaman dan gaya gravitasi :

$F_{R}=\frac{\bar{v}}{\sqrt{g y}}$

Dimana:

$F_{R}=$ Angka Froude

$\bar{v}=$ Kecepatan rata-rata aliran $(\mathrm{m} / \mathrm{det})$

$\mathrm{y}=$ Kedalaman Air $(\mathrm{m})$

$\mathrm{g}$ = gaya gravitasi (m/det)

$\mathrm{Fr}=1=$ Aliran laminer

Fr $<1=$ Aliran transisi

Fr $>1=$ Aliran turbulen

Pengukuran debit dengan cara mengukur kecepatan aliran dan menentukan luas penampang melintang sungai dan menggunakan rumus:

$\mathrm{Q}=\mathrm{V} . \mathrm{A}$

Dimana:

Q = debit aliran $\left(\mathrm{m}^{3} / \mathrm{det}\right)$

$\mathrm{V}=$ kecepatan aliran $(\mathrm{m} / \mathrm{det})$

A $\quad=$ luas penampang $\left(\mathrm{m}^{2}\right)$

Pengukuran debit dengan Alat ukur Pintu Thompson
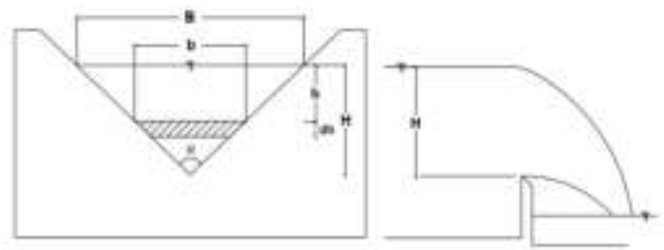

Gambar 2. Sekat Ukur Thompson atau V-notch

Dengan menggunakan persamaan deferensial dan integrasi didapat suatu rumus persamaan untuk mencari nilai debit pada alat ukur peluap segitiga, adapun persamaan tersebut adalah :
$Q=\frac{8}{15} C d \cdot \operatorname{tg} \frac{\theta}{2} \sqrt{2 \cdot g} H^{5 / 2}$

Dimana:

$\mathrm{Q}=$ debit aliran $\left(\mathrm{m}^{3} / \mathrm{det}\right)$

$\mathrm{H}=$ Kedalaman air pada bak pengukur debit (m)

$\theta=$ Sudut V- Notch $\left(\right.$ Thompson $=90^{\circ}$ )

$\mathrm{Cd}=$ Koefisien Thompson $(\mathrm{Cd}=0,62)$

$\mathrm{g}=$ Percepatan gravitasi $\left(9,8 \mathrm{~m} / \mathrm{det}^{2}\right)$

\section{Dsitribusi Ukuran Butir}

Tabel 1. Klasifikasi ukuran butir tanah menurut skala Wentworth

\begin{tabular}{|c|c|c|}
\hline \multicolumn{2}{|c|}{ Klasifikasi } & \multirow{2}{*}{$\begin{array}{c}\text { Diameter partikel } \\
(\mathrm{mm})\end{array}$} \\
\hline \multirow{4}{*}{ Berangkal } & Sangat besar & \\
\hline & Besar & $2048-1024$ \\
\hline & Sedang & $1024-512$ \\
\hline & Kecil & $512-256$ \\
\hline \multirow{2}{*}{ Kerakal } & Besar & $256-128$ \\
\hline & Kecil & $128-64$ \\
\hline \multirow{4}{*}{$\begin{array}{l}\text { Koral } \\
\text { (Kerikil } \\
\text { besar) }\end{array}$} & Sangat besar & $64-32$ \\
\hline & Kasar & $32-16$ \\
\hline & Sedang & $16-8$ \\
\hline & Halus & $8-4$ \\
\hline Kerikil & & $4-2$ \\
\hline \multirow{5}{*}{ Pasir } & Sangat besar & $2-1$ \\
\hline & Kasar & $1-0,5$ \\
\hline & Sedang & $0,5-0,25$ \\
\hline & Halus & $0,25-0,125$ \\
\hline & Sangat Halus & $0,125-0,062$ \\
\hline \multirow{4}{*}{ Lumpur } & Kasar & $0,062-0,031$ \\
\hline & Sedang & $0,031-0,016$ \\
\hline & Halus & $0,016-0,008$ \\
\hline & Sangat Halus & $0,008-0,004$ \\
\hline \multirow{4}{*}{ Lempung } & Kasar & $0,004-0,002$ \\
\hline & Sedang & $0,002-0,001$ \\
\hline & Halus & $0,001-0,0005$ \\
\hline & Sangat Halus & $0,0005-0,00024$ \\
\hline
\end{tabular}

\section{Proses Gerusan pada Tebing Sungai}

Gerusan tebing sungai adalah pengikisan tanah pada tebing - tebing sungai dan penggerusan dasar sungai oleh aliran air sungai. Dua proses berlangsungnya erosi tebing sungai adalah oleh adanya gerusan aliran sungai dan oleh adanya longsoran tanah pada 
tebing sungai. Proses yang pertama berkorelasi dengan kecepatan aliran sungai. Semakin cepat laju aliran sungai (debit puncak atau banjir) semakin besar kemungkinan terjadi erosi tebing.

\section{Bangunan Krib}

\section{Definisi Krib}

Krib adalah bangunan yang dibuat mulai dari tebing sungai ke arah tengah guna mengatur arus sungai dan tujuan utamanya adalah (Suyono Sosrodarsono,dkk, 2008):

1) Mengatur arah arus sungai

2) Mengurangi kecepatan arus sungai sepanjang tebing sungai, mempercepat sedimentasi dan menjamin keamanan tanggul atau tebing sungai terhadap gerusan.

3) Mempertahankan lebar dan kedalaman air pada alur sungai.

4) Mengkonsentrasikan arus sungai dan memudahkan penyadapan.

\section{Klasifikasi Krib}

1) Krib permeable

Pada tipe permeable air dapat mengalir melalui krib (permeable spur). Krib permeabel tersebut melindungi tebing terhadap gerusan arus sungai dengan cara meredam energi yang terkandung dalam aliran sepanjang tebing sungai dan bersamaan dengan itu mengendapkan sedimen yang terkandung dalam aliran tersebut.
2) Krib impermeable

Krib dengan konstruksi tipe impermeabel yang disebut pula krib padat, karena air sungai tidak dapat mengalir melalui tubuh krib.Krib tipe ini dipergunakan untuk membelokkan arah arus sungai dan karenanya sering terjadi gerusan yang cukup dalam didepan ujung krib tersebut atau bagian sungai di sebelah hilirnya.

3) Krib semi-permeable

Krib semi-permeable ini berfungsi ganda yaitu sebagai krib permeable dan krib padat.Biasanya bagian yang padat terletak disebelah bawah dan berfungsi pula sebagai pondasi, sedang bagian atasnya merupakan konstuksi yang permeabel disesuaikan dengan fungsi dan kondisi setempat.

4) Krib-krib silang dan memanjang

Krib yang formasinya tegak lurus atau hampir tegak lurus arah arus sungai dapat merintangi arus tersebut dan dinamakan krib melintang (transversal dyke), sedang krib yang formasinya hampir sejajar arah arus sungai disebut krib memanjang (longitudinal dyke).

\section{METODE PENELITIAN}

\section{Lokasi dan Waktu Penelitian}

Lokasi penelitian penanggulangan gerusanbertempat di Laboratorium Fakultas Teknik Universitas 
Muhammadiyah Makassar, penelitian dilakukan dalam waktu bulan Oktober 2018 - Januari 2019.

\section{Jenis penelitian dan Sumber Data}

Jenis penelitian yang digunakan adalah eksperimen laboratorium. Menurut Moh. Nasir, Ph.D (1988) dalam Yuni Cahya, 2012 observasi dibawah kondisi buatan (artificial condition), dimana kondisi tersebut dibuat dan diatur oleh peneliti dengan mengacu pada literatur-literatur yang berkaitan dengan penelitian tersebut, serta adanya kontrol dengan tujuan untuk menyelidiki ada tidaknya hubungan sebab akibat tersebut dengan memberikan perlakuan-perlakuan tertentu pada beberapa kelompok eksperimental dan menyelidiki kontrol untuk pembanding.

\section{Tahapan Penelitian}

\section{Persiapan}

Adapun kegiatan persiapan yang kami lakukan dalam penelitian ini adalah melakukan kegiatan pembersihan pada area yang akan dibangun saluran dan mempersiapkan data-data perancangan maupun alat dan bahan yang dibutuhkan.

\section{Perancangan Model}

Adapun bentuk perancangan model yang kami lakukan dalam penelitian ini yaitu :

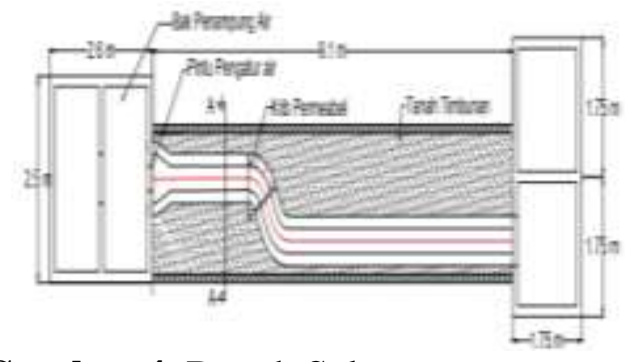

Gambar 4. Denah Saluran

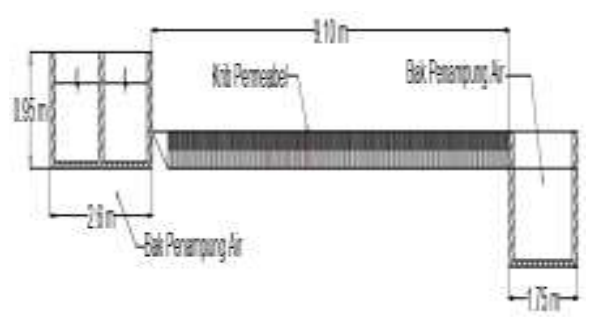

Gambar 5. Potongan Memanjang

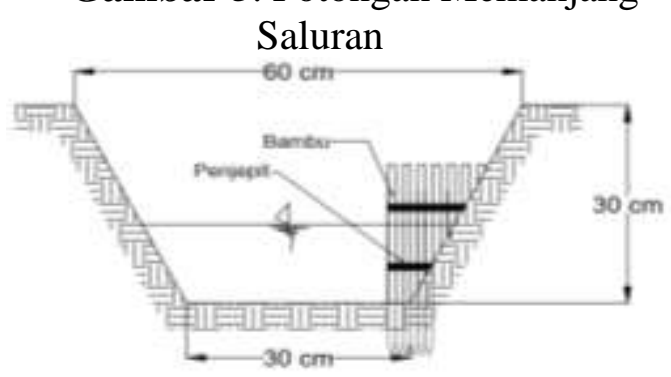

Gambar 6. Potongan Melintang Krib

Pengambilan Data

Adapun data-data yang kami ambil dalam penelitian ini adalah sebagai berikut:

1) Data kecepatan aliran (v)

Untuk data kecepatan aliran (v) diambil dari kecepatan aliran pada titik dimana aliran belum melewati bangunan krib bagian kiri, bagian tengah dan bagian kanan saluran yang dirata ratakan, yang disimbolkan dengan ( $\left.\mathrm{v}_{0}\right)$. Kemudian kecepatan aliran pada pertengahan dari bangunan krib yang disimbolkan dengan $\left(\mathrm{v}_{1}\right)$ dan kecepatan 
aliran setelah melewati bangunan krib $\left(v_{2}\right)$.

2) Data Gerusan

Pengambilan data gerusan diukur langsung pada tebing saluran yang mengalami gerusan tepatnya pada titik dimana terdapat bangunan krib semi permeabel, volume gerusan diukur dengan menggunakan meter dan menggunakan rumus luasan sesuai dengan bentuk gerusan yang terjadi.

\section{Bagan Alur Penelitian}

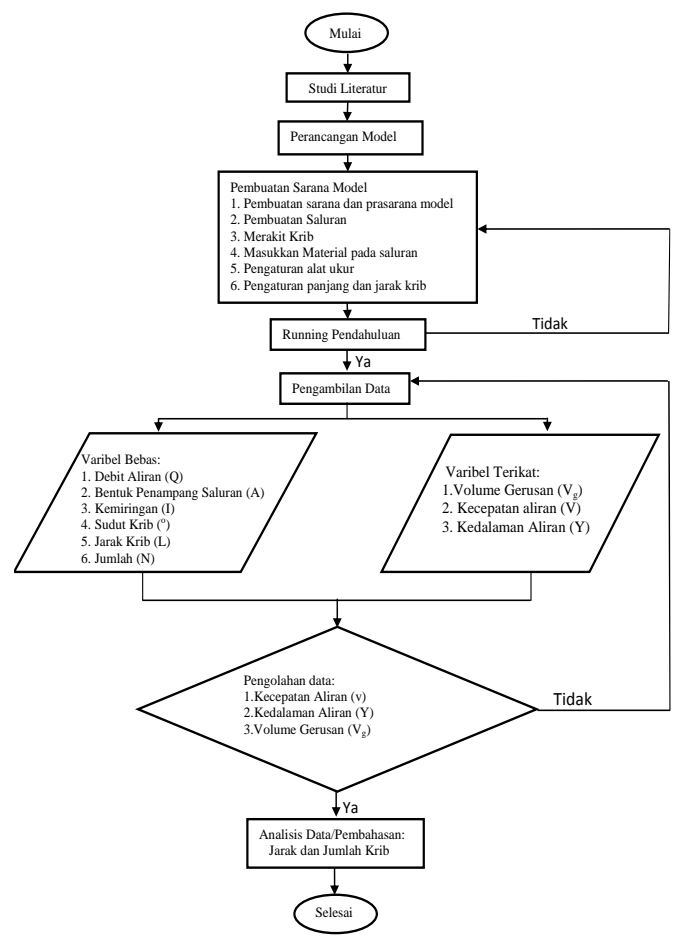

Gambar 7. Bagan Alur Penelitian

\section{HASIL DAN PEMBAHASAN}

\section{Karakteristik Material Tanah}

Karakteristik material Tanah digunakan dalam penelitian ini adalah tanah urugan dengan hasil pemeriksaan ukuran butir dengan uji saringan dan gradasi ukuran butiran yang disajikan pada tabel 4 dan gambar 8 dibawah ini.

Tabel 2.Tabel hasil perhitungan analisa saringan

\begin{tabular}{cccccc}
\hline $\begin{array}{c}\text { Saring- } \\
\text { an }\end{array}$ & $\begin{array}{c}\text { Diamt- } \\
\text { er }\end{array}$ & $\begin{array}{c}\text { Berat } \\
\text { Tertahan }\end{array}$ & $\begin{array}{c}\text { Berat } \\
\text { Komulatif }\end{array}$ & \multicolumn{2}{c}{ Persen $(\%)$} \\
\hline No. & $(\mathbf{m m})$ & (Gram) & (Gram) & Tertahan & Lolos \\
\hline 4 & 4,76 & 4 & 4 & 0,4 & 99,6 \\
\hline 8 & 2,38 & 17 & 21 & 2,1 & 97,9 \\
\hline 16 & 1,19 & 90 & 111 & 11,1 & 88,9 \\
\hline 40 & 0,595 & 143 & 254 & 25,4 & 74,6 \\
\hline 50 & 0,297 & 327 & 581 & 58,1 & 41,9 \\
\hline 100 & 0,149 & 357 & 938 & 93,8 & 6,2 \\
\hline 200 & 0,074 & 51 & 989 & 98,9 & 1,1 \\
\hline Pan & - & 11 & 1000 & 100 & 0 \\
\hline Surnery
\end{tabular}

Sumber:Hasil Analisa Saringan

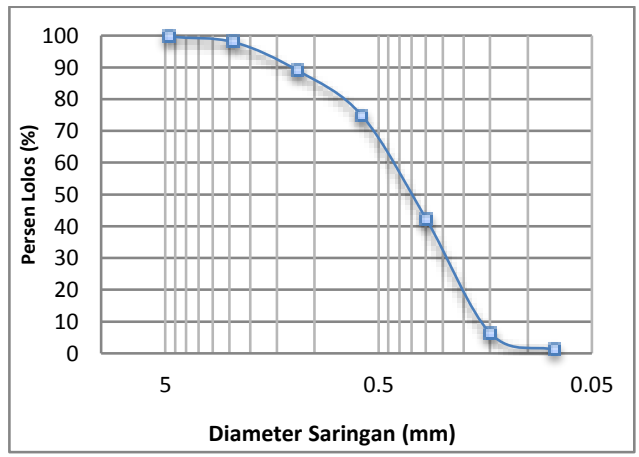

Gambar 8.Gradasi ukuran butiran tanah (sampel)

\section{Perhitungan Karakteristik Aliran}

Berdasarkan hasil uraian data data yang telah diperoleh dari hasil penelitian hubungan krib semi permeabel terhadap karakteristik aliran di peroleh hasil rekapitulasi perhitungan Bilangan Froude dan bilangan Reynoldseperti tabel berikut:

Tabel 3. Rekapitulasi Perhitungan Bilangan Froude dan Bilangan Reynold 


\begin{tabular}{|c|c|c|c|c|c|c|c|c|c|}
\hline \multirow[b]{2}{*}{$\begin{array}{c}\text { Debit Pintu } \\
\text { Thompson } \\
\text { m3/det }\end{array}$} & \multirow{2}{*}{$\begin{array}{l}\text { Waktu } \\
\text { (t) } \\
\text { (Menit) }\end{array}$} & \multicolumn{4}{|c|}{ Tanpa Pemasangan Krib } & \multicolumn{4}{|c|}{ Jarak Pemasangan Krib $35 \mathrm{~cm}$} \\
\hline & & $\begin{array}{c}\text { Bilangan } \\
\text { Froude }\end{array}$ & et. & $\begin{array}{l}\text { Bilangan } \\
\text { Reynold }\end{array}$ & Ket. & $\begin{array}{c}\text { Bilangan } \\
\text { Froude }\end{array}$ & Ket. & $\begin{array}{l}\text { Bilangan } \\
\text { Reynold }\end{array}$ & Ket. \\
\hline \multirow{3}{*}{0,0044} & 3 & 0918 & sub krit & 37 & tur & 0,778 & & 00 & turb \\
\hline & & & is & 13 & turbulen & 0,735 & itis & & turbuler \\
\hline & & & & & tur & 0,746 & & & \\
\hline \multirow{3}{*}{0,0086} & 3 & & is & 552 & turbulen & 0,856 & sub kritis & 68,24 & turbuler \\
\hline & 6 & 196 & sub kritis & 63874,77 & turbulen & 0,783 & sub kritis & 62154,19 & turbuler \\
\hline & 9 & 916 & sub kritis & 59885,55 & turbulen & 0,797 & sub kritis & 65443,02 & turbuler \\
\hline \multirow{3}{*}{0,0145} & 3 & 953 & sub kritis & 61125,18 & turbulen & 0,932 & sub kritis & 76992,18 & turbuler \\
\hline & 6 & 087 & super kritis & 69800,91 & turbulen & 0,870 & sub kritis & 64850,19 & turbuler \\
\hline & 9 & 1,218 & super kritis & 69177,38 & turbulen & 0,921 & sub kritis & 79964,05 & turbuler \\
\hline
\end{tabular}

Tabel 3. (Lanjutan)

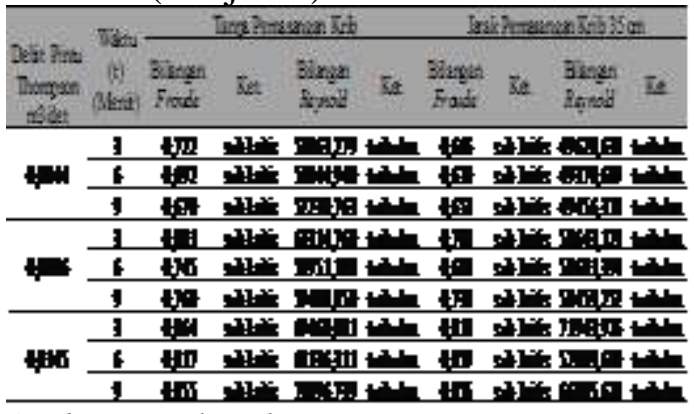

Sumber: Hasil Perhitungan

\section{Kontur dan Pola Pemasangan JarakKrib Permeabel}

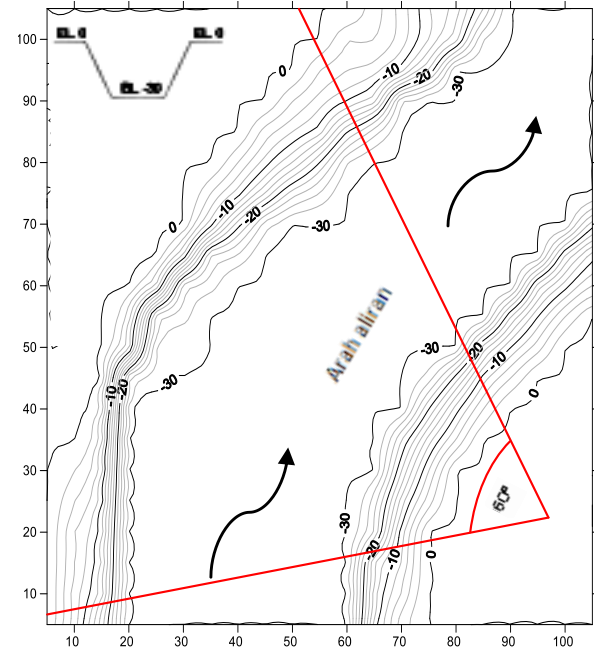

Gambar 9. Kontur Tanpa Krib

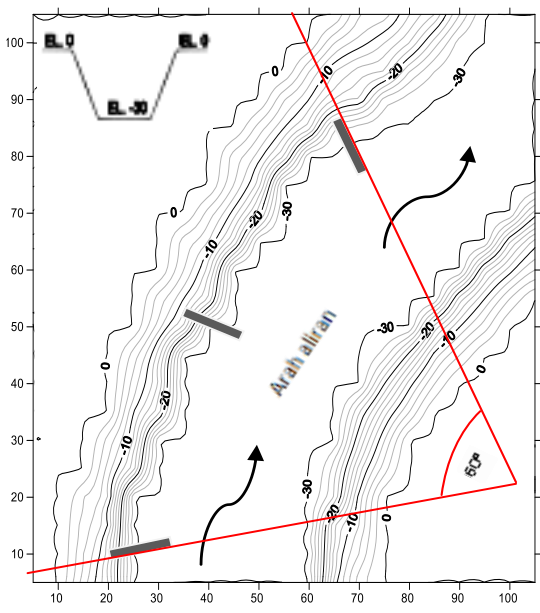

Gambar 10.Kontur dan Pola Pemasangan Krib Jarak $35 \mathrm{~cm}$

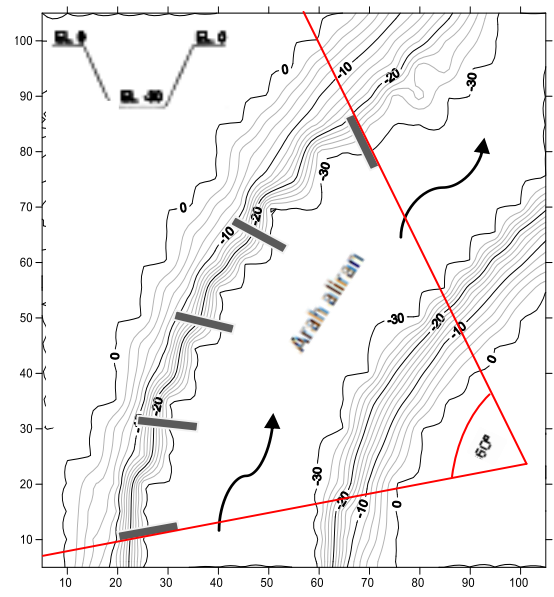

Gambar 11.Kontur dan Pola Pemasangan Krib Jarak25 cm

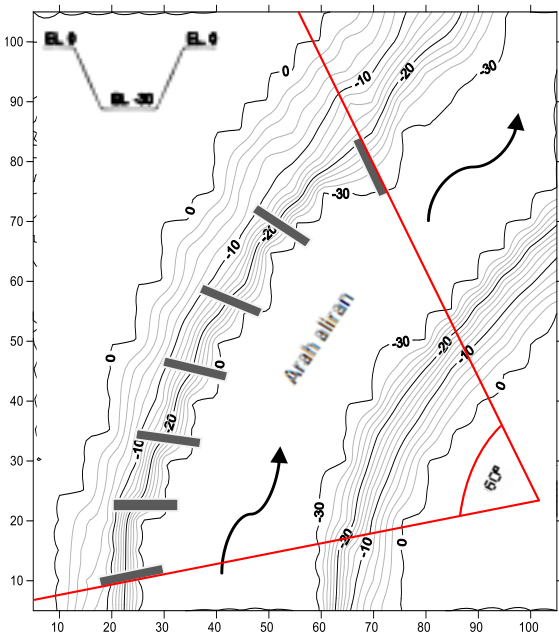

Gambar12.Kontur dan Pola Pemasangan Krib Jarak $15 \mathrm{~cm}$

\section{Analisis Pengaruh Jarak Pemasangan}

\section{Krib Permeabel}

\section{Hubungan Volume Gerusan dengan Jarak Krib Permeabel}

Berdasarkan tabel hasil penelitian yang didapatkan maka dapat dibuat tabel hubungan volume gerusan dengan jarak pemasangan krib permeabel yang diperlihatkan pada tabel 4 berikut ini.

Tabel 4. Rekapitulasi volume gerusan dengan jarak krib 
permeabel.

\begin{tabular}{|c|c|c|c|c|}
\hline \multirow[t]{2}{*}{$\begin{array}{c}\text { No } \\
\text {. }\end{array}$} & $\begin{array}{l}\text { Debit } \\
\text { (Q) }\end{array}$ & Jarak & $\begin{array}{c}\text { Waktu (t) } \\
\text { Menit }\end{array}$ & $\begin{array}{c}\text { Volume } \\
\text { Gerusan } \\
(\mathrm{Vg})\end{array}$ \\
\hline & $\mathrm{m} 3 / \mathrm{det}$ & $(\mathrm{cm})$ & & $\mathrm{m} 3$ \\
\hline 1 & \multirow{9}{*}{$\begin{array}{c}\text { Q1 } \\
0,0044\end{array}$} & \multirow{3}{*}{15} & $\mathrm{t} 1=3,00$ & 0,00202 \\
\hline 2 & & & $\mathrm{t} 2=6,00$ & 0,00289 \\
\hline 3 & & & $t 3=9,00$ & 0,00322 \\
\hline 4 & & \multirow{3}{*}{25} & $\mathrm{t} 1=3,00$ & 0,00303 \\
\hline 5 & & & $\mathrm{t} 2=6,00$ & 0,00357 \\
\hline 6 & & & $t 3=9,00$ & 0,00391 \\
\hline 7 & & \multirow{3}{*}{35} & $\mathrm{t} 1=3,00$ & 0,00408 \\
\hline 8 & & & $\mathrm{t} 2=6,00$ & 0,00495 \\
\hline 9 & & & $t 3=9,00$ & 0,00567 \\
\hline 10 & \multirow{4}{*}{$\begin{array}{c}\text { Q2 } \\
0,0086\end{array}$} & \multirow{3}{*}{15} & $\mathrm{t} 1=3,00$ & 0,00281 \\
\hline 11 & & & $\mathrm{t} 2=6,00$ & 0,00322 \\
\hline 12 & & & $t 3=9,00$ & 0,00378 \\
\hline 13 & & 25 & $\mathrm{t} 1=3,00$ & 0,00401 \\
\hline
\end{tabular}

Tabel Lanjutan (tabel 4)

\begin{tabular}{|c|c|c|c|c|}
\hline 14 & & & $\mathrm{t} 2=6,00$ & 0,00472 \\
\hline 15 & & & $t 3=9,00$ & 0,00491 \\
\hline 16 & & \multirow{3}{*}{35} & $\mathrm{t} 1=3,00$ & 0,00513 \\
\hline 17 & & & $\mathrm{t} 2=6,00$ & 0,00578 \\
\hline 18 & & & $\mathrm{t} 3=9,00$ & 0,00622 \\
\hline 19 & \multirow{9}{*}{$\begin{array}{c}\text { Q3 } \\
0,0145\end{array}$} & \multirow{3}{*}{15} & $\mathrm{t} 1=3,00$ & 0,00303 \\
\hline 20 & & & $\mathrm{t} 2=6,00$ & 0,00367 \\
\hline 21 & & & $\mathrm{t} 3=9,00$ & 0,00423 \\
\hline 22 & & \multirow{3}{*}{25} & $\mathrm{t} 1=3,00$ & 0,00482 \\
\hline 23 & & & $\mathrm{t} 2=6,00$ & 0,00542 \\
\hline 24 & & & $\mathrm{t} 3=9,00$ & 0,00614 \\
\hline 25 & & \multirow{3}{*}{35} & $\mathrm{t} 1=3,00$ & 0,00652 \\
\hline 26 & & & $\mathrm{t} 2=6,00$ & 0,00721 \\
\hline 27 & & & $\mathrm{t} 3=9,00$ & 0,00832 \\
\hline
\end{tabular}

Sumber:HasilPerhitungan

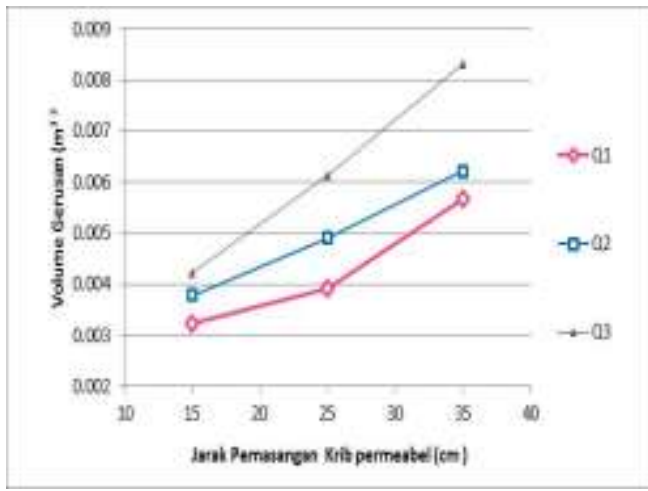

Gambar 13. Grafik Hubunga volume gerusan dengan jarak krib permeable pengaliran 9 menit.

\section{Hubungan Volume Gerusan (Vg) dengan Debit Aliran (Q)}

Berdasarkan dari data hasil peneliatian di dapatkan tabel hubungan antara volume gerusan dengan debit aliran yang diperlihatkan pada tabel 5 berikut ini.

Tabel 5. Rekapitulasi volume gerusan dengan debit aliran.

\begin{tabular}{|c|c|c|c|c|c|}
\hline \multirow[t]{2}{*}{ No. } & $\begin{array}{c}\text { Debit } \\
\text { (Q) }\end{array}$ & $\begin{array}{c}\text { Jarak } \\
\text { Krib }\end{array}$ & \multicolumn{2}{|c|}{$\begin{array}{c}\text { Waktu (t) } \\
\text { Menit }\end{array}$} & \multirow{2}{*}{$\begin{array}{c}\begin{array}{c}\text { Volume } \\
\text { Gerusan } \\
(\mathrm{Vg})\end{array} \\
\mathrm{m} 3 \\
\end{array}$} \\
\hline & $\mathrm{m} 3 / \mathrm{det}$ & $(\mathrm{cm})$ & & & \\
\hline 1 & \multirow{6}{*}{$\begin{array}{c}\text { Q1 } \\
0,0044\end{array}$} & \multirow{3}{*}{$\begin{array}{c}\text { Tanpa } \\
\text { Krib }\end{array}$} & $\mathrm{t} 1=$ & 3,00 & 0,00466 \\
\hline 2 & & & $\mathrm{t} 2=$ & 6,00 & 0,00705 \\
\hline 3 & & & $\mathrm{t} 3=$ & 9,00 & 0,00752 \\
\hline 4 & & \multirow{3}{*}{15} & $\mathrm{t} 1=$ & 3,00 & 0,00202 \\
\hline 5 & & & $\mathrm{t} 2=$ & 6,00 & 0,00289 \\
\hline 6 & & & $\mathrm{t} 3=$ & 9,00 & 0,00322 \\
\hline \multicolumn{6}{|c|}{ Tabel lanjutan (Tabel 5) } \\
\hline 7 & & \multirow{3}{*}{25} & $\mathrm{t} 1=$ & 3,00 & 0,00303 \\
\hline 8 & & & $\mathrm{t} 2=$ & 6,00 & 0,00357 \\
\hline 9 & & & $\mathrm{t} 3=$ & 9,00 & 0,00391 \\
\hline 10 & & \multirow{3}{*}{35} & $\mathrm{t} 1=$ & 3,00 & 0,00408 \\
\hline 11 & & & $\mathrm{t} 2=$ & 6,00 & 0,00495 \\
\hline 12 & & & $\mathrm{t} 3=$ & 9,00 & 0,00567 \\
\hline 13 & \multirow{12}{*}{$\begin{array}{c}\text { Q2 } \\
0,0086\end{array}$} & \multirow{3}{*}{$\begin{array}{c}\text { Tanpa } \\
\text { Krib }\end{array}$} & $\mathrm{t} 1=$ & 3,00 & 0,00706 \\
\hline 14 & & & $\mathrm{t} 2=$ & 6,00 & 0,00746 \\
\hline 15 & & & $\mathrm{t} 3=$ & 9,00 & 0,00761 \\
\hline 16 & & \multirow{3}{*}{15} & $\mathrm{t} 1=$ & 3,00 & 0,00281 \\
\hline 17 & & & $\mathrm{t} 2=$ & 6,00 & 0,00322 \\
\hline 18 & & & $\mathrm{t} 3=$ & 9,00 & 0,00378 \\
\hline 19 & & \multirow{3}{*}{25} & $\mathrm{t} 1=$ & 3,00 & 0,00401 \\
\hline 20 & & & $\mathrm{t} 2=$ & 6,00 & 0,00472 \\
\hline 21 & & & $\mathrm{t} 3=$ & 9,00 & 0,00491 \\
\hline 22 & & \multirow{3}{*}{35} & $\mathrm{t} 1=$ & 3,00 & 0,00513 \\
\hline 23 & & & $\mathrm{t} 2=$ & 6,00 & 0,00578 \\
\hline 24 & & & $t 3=$ & 9,00 & 0,00622 \\
\hline 25 & \multirow{12}{*}{$\begin{array}{c}\text { Q3 } \\
0,0086\end{array}$} & \multirow{3}{*}{$\begin{array}{c}\text { Tanpa } \\
\text { Krib }\end{array}$} & $\mathrm{t} 1=$ & 3,00 & 0,00973 \\
\hline 26 & & & $\mathrm{t} 2=$ & 6,00 & 0,01009 \\
\hline 27 & & & $\mathrm{t} 3=$ & 9,00 & 0,0117 \\
\hline 28 & & \multirow{3}{*}{15} & $\mathrm{t} 1=$ & 3,00 & 0,00303 \\
\hline 29 & & & $\mathrm{t} 2=$ & 6,00 & 0,00367 \\
\hline 30 & & & $\mathrm{t} 3=$ & 9,00 & 0,00423 \\
\hline 31 & & \multirow{3}{*}{25} & $\mathrm{t} 1=$ & 3,00 & 0,00482 \\
\hline 32 & & & $\mathrm{t} 2=$ & 6,00 & 0,00542 \\
\hline 33 & & & $\mathrm{t} 3=$ & 9,00 & 0,00614 \\
\hline 34 & & \multirow{3}{*}{35} & $\mathrm{t} 1=$ & 3,00 & 0,00652 \\
\hline 35 & & & $\mathrm{t} 2=$ & 6,00 & 0,00721 \\
\hline 36 & & & $\mathrm{t} 3=$ & 9,00 & 0,00832 \\
\hline
\end{tabular}

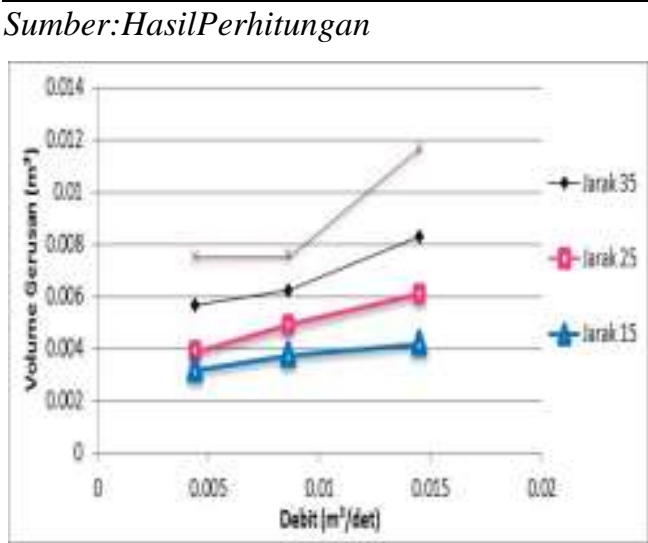

Gambar 14.Grafik Hubunga Volume 
gerusan dengan debit aliran waktu pengaliran 3 menit.

\section{PENUTUP}

\section{Kesimpulan}

1. Pengaruh pemasangan krib tipe permeabel terhadap karakteristik aliran dan tanpa pemasangan krib menyebabkan terjadinya perubahan karakteristik aliran di beberapa titik dari super kritis ke sub kritis.

2. Pemasangan jarak krib bambu tipe permeabel terhadap gerusan tebing di belokan sungai berpengaruh pada volume gerusan, dimana semakin kecil jarak pemasangan krib yang digunakan maka akan semakin kecil volume gerusan yang terjadi.

\section{Saran}

1) Pada penelitian selanjutnya diharapkan pemasangan krib tidak hanya berfokus pada belokan saja sehingga dapat diperoleh penanggulangan gerusan yang lebih efektif.

2) Diharapkan untuk selanjutnya dilakukan penelitian dan pengambilan data dibagian sebelum belokan sungai.

\section{DAFTAR PUSTAKA}

Abd Rahim A. 2017.Pengaruh Jaraj Antar Krib Terhadap Karakteristik Aliran pada Model Saluran (Skripsi), Universitas Hasanuddin. Makassar

Asdak Chay, 2014. Hidrologi dan Pengelolaan Daerah Aliran Sungai.Penerbit Gadjah Mada University Press. Yogyakarta

Cahya Yuni.2012. Kajian Perubahan Pola Gerusan Tikungan Sungai Akibat Penambahan Debit (Jurnal), Universitas Hasanuddin. Makassar

Aman Azrul, 2017. Pengaruh Sudut Pemasangan Bangunan Krib Impermeabel Dalam Menanggulangi Gerusan Tebing Sungai (Skripsi), Universitas Muhammadiyah Makassar, Makassar

Dwi Lestari, Ragil. 2016. Laporan Praktikum Teknik Irigasi. Universitas Padjajaran Bandung.

http://www.slideshare.net /mobile/frestea/24-struktursungai. png(diunduh tanggal 12 september 2018, 13.15) Gambar bentuk morfologi sungai dimodifikasi.

http://civilersc09.files.wordpress.com /2012/12/tr.png (diunduh tanggal 12 september 2018, 15.30) Gambar krib impermeabel.

http://civilersc09.files.wordpress.com /2012/12/tr.png (diunduh tanggal 12 september 2018, 15.40) Gambar krib permeabel.

http://lifeeofnadya.blogspot.com/2017/11 /pengukuran-debit-air-v-notch thompson.html?m=1.png (diunduh pada tanggal 
september 2018, 16.30) Gambar Sekat Ukur Thompson.

Hardianto Bambang, dkk. 2014. Open Channel, Closed Conduit, dan Tipe - tipe Aliran(Makalah). Universitas Islam Malang. Malang

Haris M. 2013.Studi Pola Aliran pada Krib Impermeabel di Tikungan Sungai (Skripsi), Universitas Muhammadiyah Makassar, Makassar

Kodatie Robert J, 2009. Hidrolika Terapan Aliran pada Saluran Terbuka dan Pipa. Edisi Revisi, Penerbit Andi. Yogyakarta

Loebis Joerson, M. Eng, Drs. Soewarno, Drs Suprihadi B, 1993. Hidrologi Sungai. Penerbit Yayasan Badan Penerbit Pekerjaan Umum. Jakarta

Mansida Amrullah, 2015. Buku Bahan Ajar Teknik Sungai. Universitas Muhammadiyah Makassar. Makassar

Mansida Amrullah, 2015. Buku Bahan Ajar Morfologi Sungai. Universitas Muhammadiyah Makassar. Makassar

Mardijikoen, P., 1987. Angkutan Sedimen. Diktat, Pusat Antar Universita (PAU) Ilmu Teknik, UGM, Yogyakarta

Marlina H Ayu. 2014. Studi Analisis Hidrolika Bangunan Krib Permeabel Pada Saluran Tanah (Jurnal),Universitas Sriwijaya. Palembang

Maryono, A. 2009.Eko-Hidraulik Pengelolaan Sungai Ramah Lingkungan.Penerbit Gadjah
Mada University Press. Yogyakarta

Nensi E.V Rosalina. 1992. Hidrolika Saluran Terbuka, Cetakan ketiga, Diterbitkan oleh Erlangga, Jakarta.

Paresa Jeni, 2015. Studi Pngaruh Krib Hulu Tipe Impermeabel pada Gerusan di Belokan Sungai (Studi Kasus Panjang Krib 1/10, 1/5 dan 1/3 Lebar Sungai (Jurnal). Universitas Musamus. Merauke

Setyono Ernawan, 2007. KribImpermeabel sebagaiPelindung pada Belokan Sungai (Kasus Belokan Sungai Brantas di Depan Lab. Sipil UMM)

(Jurnal),UnivrsitasMuhammadiya hMalang.Malang

Sosrodarsono Suyono.Masateru Tominang; penerjemah, Ir M. Yusuf Gayo, dkk, 2008.Perbaikan dan Pengaturan Sungai. Penerbit Pradnya Paramita. Jakarta

Suharjoko, 2008. Metode Aplikasi Bangunan Krib Sebagai Pelindung terhadap Bahaya Erosi Tebing Sungai (Jurnal). Institut Teknologi Surabaya. Surabaya

Sunaryo dkk, 2010. Pengaruh Pemasangan Krib Saluran di Tikungan $120^{\circ}$ (Jurnal), Univrsitas Andalas. Surabaya.

Sughono,1995.Buku Teknik Sipil. Penerbit Nova. Bandung. 